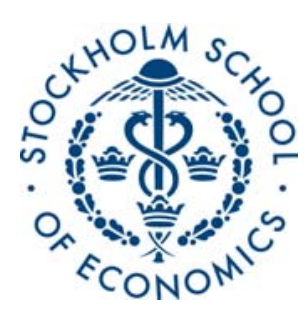

\title{
CHINA'S GROWING INFLUENCE IN SOUTHEAST ASIA - MONETARY POLICY AND EQUITY MARKETS
}

Anders C. Johansson

Stockholm School of Economics

\section{CERC Working Paper 16}

May 2010

Postal address: P.O. Box 6501, S-113 83 Stockholm, Sweden.

Office address: Holländargatan 30 Telephone: +46 87369360 Telefax: +46 8313017

E-mail: japan@hhs.se Internet: http://www.hhs.se/cerc 


\title{
China's Growing Influence in Southeast Asia - Monetary Policy and Equity Markets
}

\author{
ANDERS C. JOHANSSON* \\ Stockholm School of Economics
}

\begin{abstract}
We use structural VAR models with short-run restrictions to analyze the potential transmission of China's monetary policy shocks to equity markets in Southeast Asia. Our results show that several of the markets in the region are influenced by China's monetary policy, even though the effect is modest. The impact of a monetary expansion in China is significant and positive for four of the five Southeast Asian equity markets, indicating an increase in demand for goods and services in both China and abroad, which in turn shows up in the foreign equity market. The results provide evidence of China's growing influence in Southeast Asia and its financial markets. The transmission effect is still quite small, but can be expected to increase if the current trends of deepening economic integration between China and Southeast Asia and a maturing Chinese central bank continue.
\end{abstract}

JEL classifications: C32, E44, E52, F42, G10

Keywords: Monetary policy, stock market, structural vector autoregressive model, monetary transmission, China, Southeast Asia

\footnotetext{
* ANDERS C. JOHANSSON, Stockholm School of Economics, P.O. Box 6501, SE-113 83 Stockholm, Sweden. Phone: +46-8-736 9360. Fax: +46-8-31 30 17. Email: anders.johansson@hhs.se. Financial support from the Bank of Sweden Tercentenary Foundation, the Swedish Foundation for International Cooperation in Research and Higher Education, and the Swedish School of Advanced Asia-Pacific Studies (SSAAPS) is gratefully acknowledged.
} 


\section{Introduction}

China's economic development is remarkable in many ways. One important implication of the continuously strong economic growth over the last three decades is the growing importance China's economy has on the rest of the world. This influence is not the least apparent in East and Southeast Asia. China's growing importance in the region comes in many forms: a towering competitor when it comes to cheap labor; Chinese companies that expand their operations abroad, initially in neighboring countries; an important link in the production chain that extends across the region; and a growing market that may benefit a large number of companies in the region. This paper attempts to shed light on China's role in Southeast Asia by focusing on China's evolving monetary policy and how it affects financial markets in the region.

Most previous studies on monetary transmissions have focused on US monetary policy. This is natural, given the size of the US economy and the unique role the US dollar plays in the international financial system. However, as China's role in the world economy evolves, it becomes increasingly important to understand how its economy and economic policies are affecting other countries. Koźluk and Mehrotra (2009) point out that there is a potentially significant impact from domestic Chinese monetary policy on foreign countries. They argue that China's capital controls mean that Chinese monetary policy is most likely to affect other countries through trade. A domestic monetary expansion then results in an increase in demand for imports, something that translates into an increase in output and prices in other countries. Koźluk and Mehrotra (2009) shows that China's monetary policy indeed has a significant impact on real output in a number of East and Southeast Asian countries. This study builds upon their analysis, but focuses on a hitherto unexplored issue, that of how China's monetary 
policy affects equity markets in neighboring countries. Monetary policy effects on stock markets have been studied extensively and there is now ample evidence that monetary policy influences stock prices (e.g. Patelis, 1997; Rigobon and Sack, 2004; Bernanke and Kuttner, 2005). This paper is closely related to this literature, but focuses on how a large developing country such as China can influence market values in surrounding countries through its domestic monetary policy. Using a structural vector autoregressive (VAR) framework, we model domestic variables together with China's monetary policy. We find that expansions in China's money supply as measured by M2 result in significant and positive effects on stock markets in a majority of the countries in Southeast Asia. The results indicate that China's role in Southeast Asia is evolving and becoming more important. Our findings are closely to those of Koźluk and Mehrotra (2009) as well as related studies that focus on the influence of Japan's monetary policy and its influence on the rest of East Asia (e.g. Maćkowiak, 2006).

The rest of this paper is structured as follows. The following section introduces monetary policy in China, focusing on the development of the role of the central bank since the beginning of the economic reforms in 1978. In Section 3, we provide a brief discussion on China's changing economic relationship with Southeast Asia. Section 4 reviews the literature on international monetary policy transmissions and the relationship between monetary policy and stock markets. The structural VAR and our identification scheme are presented in Section 5. Section 6 first discusses the data and then presents and analyzes the empirical results. Finally, Section 7 concludes the paper.

\section{China's Monetary Policy}

In 1978 , the Chinese communist party began its open door policy, thereby initiating a long series of economic reforms that would result in three decades of high economic 
growth. The reforms were gradual in nature and over time came to cover most aspects of the economy, including the monetary system. An important step towards a functioning monetary system was taken in 1984, when it was decided that the People's Bank of China (PBC) should function as the country's central bank. The next major step towards a more complete monetary system was taken in 1995, when the Law of the People's Bank of China was enacted. It was decided that the objective of monetary policy was to stimulate domestic economic growth while at the same time maintaining a stable exchange rate and prices (Nagai and Wang, 2007). At the same time, the first real steps were taken to separate the so-called Big Four, i.e. the large state-owned banks, from economic policy. Three policy banks were established: the State Development Bank, the Export-Import Bank, and the Agricultural Development Bank. These policy banks took over the policy portfolios of the Big Four, thus freeing them from the burden of adhering to central policy and letting them focus on commercial loans. ${ }^{1}$ Overall, the goal was thus to create a well-functioning monetary and financial system.

In 1998, the most significant change in the monetary system took place. The PBC abolished the official loan targets for commercial banks. These loan targets had until then been written quarterly and annually. An annual guidance plan took its place, a plan that no longer has a significant meaning as a target. It is more or less used as a guide when commercial banks make their projections and also as a macroeconomic indicator for the PBC (Nagai and Wang, 2007). The elimination of bank credit targeting meant that the PBC focused on its balance sheet in the management of the domestic monetary base.

\footnotetext{
${ }^{1}$ It should be noted that the reform meant to separate the big state-owned banks from fiscal and monetary policy was not an easy task, and the banks have continued to play a central role in domestic economic policy. Shih (2007, p 32) points out that political incentives for bank managers combined with weak institutional capacity in the new policy banks has meant that the large commercial banks have continued to used as instruments for economic policy.
} 
That year, the PBC also began its open market operations when it initiated bond trading with cash (Green, 2005).

In July 2005, an important measure was taken in the pursuit of improving the ability for the PBC to carry out a more efficient monetary policy. The announcement stated that the exchange rate system was to be reformed. Until then, the Chinese renminbi (RMB) was held fixed against the US dollar. If a country decides to fix its exchange rate, it affectively limits its ability to carry out independent monetary policy. If the country in question is small, its monetary policy is effectively decided in the country with the main currency. A typical example of this is Hong Kong and US monetary policy (Rodríguez and Rowe, 2007). Even for a larger country such as China, a fixed exchange rate most likely results in a significant monetary policy transmission. For instance, Johansson (2009) shows that US monetary policy influences real output in China. After the exchange rate reform in 2005 , the Chinese renminbi was pegged to a wider basket of currencies rather than just the US dollar and allowed to vary within a narrow band. ${ }^{2}$ When the global financial crisis spread from the US to the rest of the world, the Chinese authorities decided to once more peg the currency to the US dollar in order to decrease exchange rate volatility and minimize the potential negative impact on Chinese exports. Overall, the PBC is slowly moving towards becoming a modern central bank comparable to those in developed countries. However, a number of issues remain, not the least the lack of standard monetary instruments based on interest rates.

\footnotetext{
${ }^{2}$ Even though the reform constituted an important first step in the development of China's monetary system, it is clear that the change did not immediately translate into a much more flexible exchange rate framework. For example, Frankel and Wei (2007) argue that the weight of the US dollar has remained heavy in the new basket of currencies.
} 


\section{China and Southeast Asia}

China's role in Southeast Asia is growing in several different areas. In terms of the domestic economies in the region, China is quickly becoming one of their major trading partners. Figure 1 shows the changing nature of imports from China for the five countries included in this study. Starting with modest levels of somewhere around 3\% on average in the late 1980s, imports from China have grown much faster than total imports. In the end of 2008, imports from China made up more than $10 \%$ on average for the five countries. The only country that has not experienced the same dramatic increase in imports from China is the Philippines.

[FIGURE 1 HERE]

Figure 2 shows the corresponding development for exports from the five Southeast Asian countries. Again, the average share of exports to China to total exports was quite modest in the late 1980 s at around $3 \%$. In the end of 2008 , the share of exports to China had grown to an average of approximately $10 \%$. In terms of exports, the Philippines have also experienced a significant increase in exports to China during the last decade. Overall, the trade patterns depicted in the two figures are clear indicators of how China and its economy are quickly becoming increasingly important for the different countries in Southeast Asia.

[FIGURE 2 HERE]

Brooks and Hua (2009) argue that it is more likely that countries that are connected through production sharing will experience common shocks in different forms. This is 
because they tend to specialize in similar or related industries. Besides the direct relationships in terms of industry-specific cooperation, firms increasingly operate across country borders. This is especially true in East and Southeast Asia, where the regional "production chain" means that firms carry out different parts of their production in different countries depending on the countries' comparative advantages (Johansson, 2010). Bussière and Mehl (2008) show that trade linkages between China and East and Southeast Asia are stronger than suggested by mere economic fundamentals, while the link between India and the region is weaker. One important reason for this is the strong linkages in the production chain across the region, in which China plays an integral and ever more important part. It is worth noting that over $70 \%$ of intraregional trade is comprised of intermediate goods used in further production and half of it is driven by a final demand located outside the region (Brooks and Hua, 2009). As this production pattern becomes more and more important in East and Southeast Asia, firms in Southeast Asia will also become increasingly dependent on macroeconomic and monetary shocks in China.

Besides the strong linkages due to regional production chains and transnational companies working in the region, some of the equity markets outside of China are becoming more and more related to the Chinese economy and stock markets. Naturally, Hong Kong has for a long time been the first stop for Chinese companies in their decisions to list abroad. However, countries such as Singapore have also attracted Chinese-based companies to their stock exchange. In 2006, more than 100 Chinese firms were listed in Singapore, constituting close to $15 \%$ of the total listings on that stock exchange. This trend is likely to continue, even though the countries with less mature equity markets are not as likely to experience a significant increase in listings of Chinese companies in the near future. 


\section{Theoretical Framework}

There is an abundant literature on monetary policy and its impact on different parts of the economy. In this section, we focus on two strands in this literature: studies on monetary policy transmissions across countries and research on how monetary policy impacts equity markets. These different research areas provide a general framework which we then use to set up the econometric model and analyze the empirical results.

\subsection{International Monetary Policy Transmissions}

It is possible to argue in favor of both positive and negative international monetary policy transmission effects. The classical Mundell-Fleming model posits that a monetary policy expansion in the home country results in a negative effect on foreign output. The negative effect is a result of the switch in expenditure that follows the depreciation of the home country's currency. In the classical Mundell-Fleming framework, there is thus a 'beggar-thy-neighbor' effect on other economies occurring after a domestic monetary expansion. In the New Open Economy Macroeconomics literature, the results are not as clear. Betts and Devereux $(1996,2000,2001)$ show that it is the price-setting behavior of firms in different countries that determines the direction of the monetary policy transmission across countries. Schmidt (2006) builds on this approach and show that asymmetries in price-setting behavior will lead to monetary policy transmissions that are in line with most empirical studies that show a positive effect of monetary policy transmissions. Another and perhaps more direct argument is that a monetary expansion in a large country such as the US will result in a decrease in the world real interest rate. This will in effect increase the demand for goods and services produced in both the US and other countries. If this positive effect dominates the expenditure-switching effect seen in the Mundell-Fleming framework, the overall effect on other countries should thus be positive. 
Kim (2001) applies a structural vector autoregressive (VAR) model when he analyzes the international transmission of US monetary policy shocks. Focusing on the non-US G-6 countries, he finds that a US monetary policy expansion results in increases in income in the rest of the G-6 countries. He also shows that such transmissions result in a short-run worsening but a long-term improvement of the US trade balance. In a related study, Canova (2005) also applies a structural VAR when analyzing international monetary policy transmissions. Canova finds that US monetary policy shocks have a significant effect on the Latin American economies. His results also indicate that financial channels are crucial for the monetary policy transmission. Holman and Neuman (2002) instead analyze monetary policy transmissions from the US to Canada. They identify positive monetary policy transmission effects on Canada's output, consumption, and investment. In a study on monetary policy transmission and capital controls, Miniane and Rogers (2007) provide evidence that countries with less open capital accounts are as likely to be affected by international monetary policy transmissions. Their results are of particular interest to our analysis, since Thailand imposed capital controls in late 2006. Rodríguez and Rowe (1007) analyze how US monetary policy is transferred to a country with a fixed exchange rate regime against the US dollar. They find that US monetary policy shocks are transmitted to real output in Hong Kong. In a related study, Johansson (2009) also show that US monetary policy does seem to have significant effects on the Chinese economy.

Besides research that focuses on US monetary policy and its influence on the rest of the world, other studies have analyzed how other important central banks and their monetary policy influence other economies. Callen and McKibbin (2001) use a GCubed model on Asia Pacific to analyze how shocks to the Japanese economy affect the region. Their model implies that Japanese monetary policy shocks will not have a 
significant effect on the rest of the region. Coenen and Wieland (2003) analyze how monetary policy shocks in Japan can affect the country's main trading partners. Their analysis is based on the assumption that all three central banks in Japan, the US and Europe follow Taylor's nominal interest rate rule. Coenen and Wieland's findings are in favor of a significant beggar-thy-neighbor effect. Maćkowiak (2006) estimates structural VARs to analyze how Japan's monetary policy transmits to other countries in East Asia. He finds that the effect of Japan's monetary policy on real output, trade balances and exchange rates in East Asia has been quite modest. Finally, Koźluk and Mehrotra (2009) study China's monetary policy and its effects on East and Southeast Asia. Their findings show that monetary policy conducted in China does indeed have a significant effect on real output in other countries in the region.

\subsection{Monetary Policy and Equity Markets}

There is a large literature that looks at the impact of monetary policy on equity markets. Early studies tend to apply recursive VAR models to investigate the relationship between domestic monetary policy and the stock market. Thorbecke (1997) incorporates a number of alternative measures of monetary policy (innovations in the federal funds rate and nonborrowed reserves, an event study of policy changes, and narrative indicators) in a recursive VAR. He finds that a monetary expansion, regardless of measure, leads to an increase in stock returns. While Thorbecke's focus is on contemporaneous stock returns, Patelis (1997) instead analyzes monetary policy shocks and their impact on future expected stock returns. He finds that monetary policy can be used to predict future stock returns. Lastrapes (1998) uses a structural VAR with long-term restrictions to analyze how monetary policy impacts domestic stock and bond markets in the G-8 markets. He finds that financial markets are affected by monetary policy in most countries, but that the magnitude of the impact differs across the sample. Instead of looking at the federal 
funds rate or other standard indicators of monetary policy in the US, Rigobon and Sack (2004) and Bernanke and Kuttner (2005) focus on futures markets which they claim enable a cleaner isolation of the unexpected part of monetary policy decisions. ${ }^{3}$ While Rigobon and Sack apply a new heteroscedasticity-based estimator to take potential simultaneity bias into account, Bernanke and Kuttner use an event-study approach and control for information that is likely to jointly affect monetary policy and stock prices. Rigobon and Sack show significant changes in stock prices as a result of unexpected interest rate changes, and Bernanke and Kuttner find that an unexpected 25 basis point decrease in the federal funds rate results in an approximately $1 \%$ increase in the stock market. Finally, Li, İsçan and Xu (2010) use a structural VAR to analyze if trade and financial openness affect the impact of monetary policy shocks to stock prices in the US and Canada. Their results indicate that differences in stock market responses to monetary policy shocks are driven primarily by financial market openness.

The empirical results in the two strands of literature discussed above indicate that monetary policy has a significant effect on equity markets and that monetary policy shocks in larger countries often transmits to other countries. Using both theoretical and empirical studies, it can thus be argued that monetary policy in a larger country is likely to affect other countries.

\section{Methodology}

Our main interest is the relationship between China's monetary policy and equity markets in East Asia. However, we will model this relationship in a general equilibrium

\footnotetext{
${ }^{3}$ In a related study, Rigobon and Sack (2003) analyze the impact that stock prices have on monetary policy. They find that a 5\% increase in stock prices increase the likelihood that the Federal Reserve tighten monetary policy with 25 basis points by approximately a half.
} 
framework (e.g. Li İsçan and Xu, 2010). In that framework, a number of macroeconomic variables interact contemporaneously. To accomplish this, we will use a structural vector autoregressive (VAR) setup. Starting with a reduced form setup, we can write the VAR model as:

$y_{t}=A_{1} y_{t-1}+\cdots+A_{p} y_{t-p}+u_{t}$

where $y_{t}=\left(y_{1 t}, \ldots y_{K t}\right)$ ' is a $K \times 1$ vector of variables, $u_{t}$ is a $K \times 1$ vector of white noises with expected values of $E\left(u_{t}\right)=0$ with a time-invariant covariance matrix $\Sigma_{u}, p$ is the order of the VAR model, and the $A_{i}$ are set $K \times K$ matrices of coefficients. In order to analyze how China's monetary policy affects different variables in the system, we apply a structural VAR model. To identify the different structural shocks in the system, we need to impose a number of restrictions on the contemporaneous effects. The reduced-form disturbances $u_{t}$ are linear combinations of the structural shocks, denoted by $\varepsilon_{t}$, where $\varepsilon_{t} \sim\left(0, I_{K}\right)$. The relationship between the reduced-form disturbances and the structural shocks can thus be written as $u_{t}=\mathrm{B} \varepsilon_{t}$, where $\mathrm{B}$ is a structural form parameter matrix. We can write a general form of the structural VAR as:

$\mathrm{A} y_{t}=A_{1}^{*} y_{t-1}+\cdots+A_{p}^{*} y_{t-p}+\mathrm{B} \varepsilon_{t}$.

The matrix A allows us to model the instantaneous relations among the variables, while the $A_{i}^{*}$ for $i=1, \ldots, p$ are $K \times K$ coefficient matrices. Matrix $A_{i}$ is related to $A_{i}^{*}$ the following way: $\mathrm{A}^{-1} A_{j}^{*}=A_{j}$. Finally, the relationship between the reduced-form and structural form errors can be written as: 
$u_{t}=\mathrm{A}^{-1} \mathrm{~B} \varepsilon_{t}$.

The structural model that we focus on includes four endogenous variables, three domestic and one external. The external variable is China's money supply, M2 (labeled $m c$ ). While the PBC utilizes a number of different monetary instruments, money supply plays a very important role in China's monetary policy. ${ }^{4}$ The three domestic variables are: real output measured by industrial or manufacturing production $(y)$, the price level measured by the consumption price index $(p)$, and the domestic real stock price measured by a broad market index normalized by the consumer price index (s). The choice of model variables follows related research on monetary policy and stock markets (e.g. Li, İsçan, and Xu, 2010). We also tried to include additional domestic and international variables, but the relatively short time period resulted in less robust estimates and issues with the structural form of the model. We therefore chose to focus on a somewhat more parsimonious setup with a total of four variables.

To be able to identify the parameters in the structural-form model, we need restrictions on the parameter matrices. For the $K$-dimensional system above, there are a total of $2 K^{2}$ elements in the structural form matrices A and B. We cannot identify more than $K(K+1) / 2$ in the structural form. In total, we therefore need a total of $2 K^{2}-K(K+1) / 2$ $=K^{2}+K(K-1) / 2$ to identify the model (Breitung, Brüggeman and Lütkepohl, 2004). Using the notations for the different endogenous variables in the system, we can thus write the structural model as:

\footnotetext{
${ }^{4}$ Similarly, Koźluk and Mehrotra (2009) use money supply when analyzing the impact of China's monetary policy on a number of East and Southeast Asian countries.
} 


$$
\left[\begin{array}{cccc}
1 & 0 & 0 & 0 \\
0 & 1 & 0 & 0 \\
a_{31} & a_{32} & 1 & a_{34} \\
0 & 0 & 0 & 1
\end{array}\right]\left[\begin{array}{c}
u_{t}^{y} \\
u_{t}^{p} \\
u_{t}^{s} \\
u_{t}^{m c}
\end{array}\right]=\left[\begin{array}{cccc}
b_{11} & 0 & 0 & 0 \\
0 & b_{22} & 0 & 0 \\
0 & 0 & b_{33} & 0 \\
0 & 0 & 0 & b_{44}
\end{array}\right]\left[\begin{array}{c}
\varepsilon_{t}^{y} \\
\varepsilon_{t}^{p} \\
\varepsilon_{t}^{s} \\
\varepsilon_{t}^{m c}
\end{array}\right] .
$$

The identification design above can be seen as combining critical components from existing research on the relationship between monetary policy and equity markets and research that focuses on cross-country monetary policy transmissions (e.g. Li, İsçan, and Xu, 2010; Koźluk and Mehrotra, 2009). We have the following four structural form shocks: domestic industrial or manufacturing production shocks $\left(\varepsilon_{t}^{y}\right)$, general price shocks $\left(\varepsilon_{t}^{p}\right)$, real stock market price shocks $\left(\varepsilon_{t}^{s}\right)$, and Chinese monetary policy shocks $\left(\varepsilon_{t}^{m c}\right)$. Starting with the first row in the system presented in Equation (4), industrial and manufacturing production does not respond to monetary policy instantaneously, due to inertia in economic activity. The same goes for domestic price levels in the different Southeast Asian countries. This assumption follows the setup found in related studies, including Sims and Zha (2004). The setup in the third row in Equation (3) assumes that the stock market reacts instantaneously to changes in the other three variables. The fourth row of Equation (4) shows that we assume that the PBC sets its monetary policy without taking contemporaneous effects of the other variables into account. It is natural to assume that China's central bank does not consider issues such as industrial production, prices or real stock prices in Southeast Asia when it conducts its monetary policy.

It could be argued that the impact of domestic monetary policy is dependent on the choice of exchange rate regime in each of the East Asian countries included in the sample. For instance, Koźluk and Mehrotra (2009) use a structural setup that takes this into account for Hong Kong, which for a long time have had a currency board that 
effectively ties the Hong Kong dollar to the US dollar. Most of other countries included in this study have had floating exchange rate regimes during the analyzed period, even though some of them have experienced both fixed and floating regime settings. For example, the Malaysian government decided to peg the exchange rate against the US dollar during the Asian financial crisis and then changed to a managed float in July 2005. While we do not analyze the matter further here, it is worth noting that the Chinese exchange rate was fixed against the US dollar in 1994. This changed in July 2005, when the Chinese monetary authorities changed from a fixed exchange rate to a crawling peg based on a basket of different currencies. The Chinese renminbi was unofficially pegged against the US dollar again in July 2008 as a result of the global financial crisis.

\section{Empirical Analysis}

\subsection{Data}

The data used in this study is monthly and cover the period from January 1998 to December 2009. The relatively short time period is a result of the fact that the PBC abandoned bank credit targeting in 1998 and started to focus on its balance sheet when handling the monetary base after this change. We therefore argue that it is more useful to analyze the influence of China's monetary policy from that year onwards. The data are sourced from Datastream and IMF's International Financial Statistics. Since interest rates have not yet come to play the same role as in more developed economies, China's monetary policy is measured by money supply (M2). We measure real output by an industrial production index, except for in the cases of Singapore and Thailand, for which we use manufacturing indices. Price levels are measured by consumer price indices (CPI) for all five countries. The time series for industrial and manufacturing production, CPI, and China's money supply are seasonally adjusted using the Census X-12 procedure. To 
measure movements in the stock market, we use broad stock indices. Since we want to be able to interpret changes in stock prices in real terms, the nominal stock indices are normalized by CPIs. All variables are expressed in natural logarithms and the structural VAR models are estimated in first differences to guarantee stationarity in all variables. Finally, the lag length in the VAR is set to two. Hannan-Quinn information criterion indicates 1-2 lags for most countries. Furthermore, the likelihood ratio test for the overidentified model showed that including more lags resulted in a loss of robustness for the structural VAR model developed above. We therefore choose the somewhat parsimonious setup with two lags.

\subsection{Empirical Results}

The four-variable structural VAR is estimated for each of the five Southeast Asian countries. Before we analyze the results, we check the identifications scheme with a standard likelihood ratio test. The results are shown in Table 1. The null hypothesis is that any over-identifying restrictions are valid. In all five cases, we cannot reject the null at any conventional level. This means that we can use the identifying scheme presented in the previous section when we analyze the impact of China's monetary policy on Southeast Asian equity markets.

[TABLE 1 HERE]

Having estimated the structural VAR model for each of the five countries, we then focus on impulse response functions for the different variables. In this section, we present impulse response functions that are obtained by bootstrapping methods with 1,000 replications. Figure 3 shows the impulse responses for Chinese monetary policy shocks. Even though our main focus is on the equity market, all four variables in the system are 
included in the figure for completeness. China's monetary policy itself is naturally affected by these shocks. CPI and real output in Indonesia, on the other hand, do not show any signs of such effects. Finally, looking at the impulse response function for the Indonesian equity market, there is a significant positive effect as a result of Chinese monetary policy shocks.

\section{[FIGURE 3 HERE]}

Next, we look at the results from the estimations for Malaysia. Figure 4 shows the same setup as Figure 3. The impact on Chinese monetary policy is almost identical to the one from the estimation on Indonesia. Again, neither CPI nor real output show signs of a significant response to shocks in Chinese monetary policy. The impact on the Malaysian stock market, on the other hand, is significant. Again, an unexpected monetary expansion in China leads to an increase in the Malaysia stock market. The positive effect is small and short lived, but still statistically significant.

\section{[FIGURE 4 HERE]}

Figure 5 presents the impulse response functions for the Philippines. Chinese monetary policy show similar signs as for the previous two countries. The impact on Philippine CPI is insignificant, while a monetary expansion in China seems to have a modest and short-lived but still significant effect on real output in the Philippines. This result is supported in Koźluk and Mehrotra (2009), who find that Chinese monetary policy shocks constitute a major source of variation in GDP for the Philippines. Opposite to the results for Indonesia and Malaysia, Chinese monetary policy shocks do not have a significant 
effect on the stock market in the Philippines. Section 3 indicated that the trade link between China and the Philippines seem to be somewhat lagging behind that of the other countries in the region, something that may help explain the non-significant response of the Philippine stock market to Chinese monetary policy shocks.

\section{[FIGURE 5 HERE]}

We then move on to Singapore. As mentioned previously, the fact that an increasing number of firms listed in Singapore are domiciled in China means that we expect Chinese monetary policy to have at least a similar effect on the Singapore stock market as on the Indonesian and Malaysian stock markets. The results of the estimation for Singapore are shown in Figure 6. Starting with the effect on Chinese monetary policy, the pattern is similar to the previous cases. Both Singapore's CPI and real output are unaffected by unexpected Chinese monetary policy shocks. However, Singapore stock prices increases as a result of a sudden Chinese monetary expansion.

\section{[FIGURE 6 HERE]}

Finally, we look at response to Chinese monetary policy shocks in Thailand. The response of Chinese monetary policy itself is again positive and similar to those from the previous estimations. Neither CPI nor real output as measured by manufacturing production seem to be responding to Chinese monetary policy shocks. However, an unexpected Chinese monetary expansion results in a positive effect on the Thai stock market. 
The impulse responses from the structural VARs reveal that four of the five equity markets in the sample show signs of significant and positive effects after unexpected changes in Chinese monetary policy. The effects are however modest and short lived. To complement the analysis based on impulse responses, we also report forecast error variance decompositions for the five equity markets in Table 2. The standard errors are listed with forecast horizons of 4, 8, and 12 months, respectively. The results indicate that only Indonesia and Thailand have significant contributions to the variance of stock prices. Also, the effects are very modest and close to but different from zero.

[TABLE 2 HERE]

The overall results from the impulse response function estimations indicate that four of the five Southeast Asian equity markets in the study are positively affected by Chinese monetary policy shocks. The forecast error variance decompositions show that Chinese monetary policy only contributes significantly to the forecast error variance in two of the five markets. The structural VAR thus leads us to conclude that Chinese monetary policy has a significant on a majority of the Southeast Asian markets in the sample. However, the effects are very modest. The discussion on the relationship between China and Southeast Asia in Section 3 showed that China's economic ties to Southeast Asia have grown fast from very modest levels during the 1990s. If this trend continues, the impact of Chinese monetary policy on regional equity markets in Southeast Asia can be expected to become more important. Furthermore, as the PBC continues to evolve into a central bank similar to those in developed countries, the impacts of its policy decisions will most likely increase not only at home, but abroad as well. 


\section{Conclusion}

Previous research shows that monetary policy in large economies such as the US often transmits across country borders, especially to countries with significant economic ties and/or exchange rate regimes with close connections to the large country in question. Research also shows that monetary expansions in general tend to have a significant and usually positive effect on the stock markets. In this study, we have analyzed the impact of China's monetary policy shocks on five Southeast Asian equity markets. We thus combine the two strands of literature to analyze international monetary policy transmissions to international equity markets.

Relying on economic theory, we impose short-run restrictions in a structural VAR model and then estimate impulse response functions as well as variance decompositions using bootstrap procedures. Using data from 1998, the year when the PBC abandoned bank credit targeting, we estimate the four-variable structural VAR models for Indonesia, Malaysia, Philippines, Singapore, and Thailand. Impulse response functions indicate that China's monetary policy has a significant impact on all the Southeast Asian stock markets except that of the Philippines. Forecast error variance decompositions show that the relationship is quite modest, with forecast error variance in only two of the five markets being affected over different horizons.

Even though the transmission effects are modest, they are still statistically significant, which indicates that China's influence in Southeast Asia is increasing. Trade patterns in Southeast Asia and the growing importance of the regional production chains indicate that this influence will continue to grow. This means that we can expect that China's monetary policy will become increasingly important for the Southeast Asian economies as well as the regional equity markets. This study complements earlier research on international monetary policy transmissions and economic integration. It also 
sheds light on how monetary policy affects equity markets in different countries and China's increasing influence in Southeast Asia. The results open up for a number of related future research topics. For instance, bonds and other asset classes in the region are possibly affected by the growing importance of China and its monetary policy. Outcomes of such future studies are to a large extent dependent on the continued reform of China's monetary system and the development of the PBC into a modern and well-functioning central bank. 


\section{Bibliography}

Bernanke, B.S. \& K.N. Kuttner (2005) What Explains the Stock Market's Reaction to Federal Reserve Policy? Journal of Finance 60, 1221-1257.

Betts, C. \& M.B. Devereux (1996) The Exchange Rate in a Model of Pricing-to-Market. European Economic Review 40, 1007-1021.

Betts, C. \& M.B. Devereux (2000) Exchange Rate Dynamics in a Model of Pricing-toMarket. Journal of International Economics 50, 215-244.

Betts, C. \& M.B. Devereux (2001) The International Effects of Monetary and Fiscal Policy in a Two-Country Model. In Essays in Honor of Robert A. Mundell, M. Obstfeld \& G. Calvo (eds). Cambridge, MA: MIT Press, 9-52.

Bussière, M. \& A. Mehl (2008) China's and India's Roles in Global Trade and Finance: Twin Titans for the New Millenium? European Central Bank Occasional Paper Series, No. 80.

Breitung, J., R. Brüggemann \& H. Lütkepohl (2004). Structural Vector Autoregressive Modeling and Impulse Responses, in Lütkepohl, H. and M. Krätzig (eds), Applied Time Series Econometrics. Cambridge: Cambridge University Press, 159-196.

Brooks, D.H. \& C. Hu (2009) Asian Trade and Global Linkages. Asian Development Review 26, 103-128.

Canova, F. (2005) The Transmission of US Shocks to Latin America. Journal of Applied Econometrics 20, 229-251.

Coenen, G. \& V. Wieland (2003) The Zero-Interest-Rate Bound and the Role of the Exchange Rate for Monetary Policy in Japan. Journal of Monetary Economics 50, 1071-1101.

Frankel, J.A. \& S.-J. Wei (2007) Assessing China's Exchange Rate Regime. Economic Policy 22, 575-627. 
Green, S. (2005) Making Monetary Policy Work in China: A Report from the Money Market Front Line. Stanford Center for International Development Working Paper, No. 245 .

Holman, J.A \& R.M. Neumann (2002) Evidence on the Cross-Country Transmission of Monetary Shocks. Applied Economics 34, 1837-1857.

Johansson, A.C. (2009) Is U.S. Money Causing China's Output? China Economic Review 20, 732-741.

Johansson, A.C. (2010) China's Financial Market Integration with the World. Chinese Economic and Business Studies, forthcoming.

Kim, S. (2001) International Transmission of U.S. Monetary Policy Shocks: Evidence from VAR's. Journal of Monetary Economics 48, 339-372.

Koźluk, T. \& A. Mehrotra (2009) The Impact of Chinese Monetary Policy Shocks on East and South-East Asia. Economics of Transition 17, 121-145.

Lastrapes, W.D. (1998) International Evidence on Equity Prices, Interest Rates and Money. Journal of International Money and Finance 17, 377-406.

Li, Y.D., T.B. İsçan \& K. Xu (2010) The Impact of Monetary Policy Shocks on Stock Prices: Evidence from Canada and the United States. Journal of International Money and Finance, forthcoming.

Maćkowiak, B. (2006) What Does the Bank of Japan Do to East Asia? Journal of International Economics 70, 253-270.

Miniane, J. \& J.H. Rogers (2007) Capital Controls and the International Transmission of U.S. Monetary Shocks. Journal of Money, Credit and Banking 39, 1003-1035.

Nagai, S. \& H. Wang (2007) Money Market Operations in China: Monetary Policy or FX Policy? Bank of Japan Working Paper, No. 07-E-13.

Patelis, A.D. (1997) Stock Return Predictability and the Role of Monetary Policy. Journal of Finance 52, 1951-1972. 
Rodríguez, G. \& N. Rowe (2007) Why U.S. Money Does not Cause U.S. Output, But Does Cause Hong Kong Output. Journal of International Money and Finance 26, 1174-1186.

Rigobon, R. \& B. Sack (2003) Measuring the Reaction of Monetary Policy to the Stock Market. Quarterly Journal of Economics 118, 639-669.

Rigobon, R. \& B. Sack (2004) The Impact of Monetary Policy on Asset Prices. Journal of Monetary Economics 51, 1553-1575.

Schmidt, C. (2006) International Transmission Effects of Monetary Policy Shocks: Can Asymmetric Price Setting Explain the Stylized Facts? International Journal of Finance and Economics 11, 205-218.

Shih, V. (2007) Factions and Finance in China: Elite Conflict and Inflation. Cambridge, MA: Cambridge University Press.

Sims, C. A. \& T. Zha (2006) Does Monetary Policy Generate Recessions? Macroeconomic Dynamics 10, 231-272.

Thorbecke, W. (1997) On Stock Market Returns and Monetary Policy. Journal of Finance 52, 635-654. 
Table 1. Test for Over-Identifying Restrictions

\begin{tabular}{lcl} 
Country & \multicolumn{2}{c}{ Likelihood Ratio Test } \\
\hline Indonesia & 3.614 & $(0.306)$ \\
Malaysia & 3.972 & $(0.265)$ \\
Philippines & 5.546 & $(0.136)$ \\
Singapore & 5.992 & $(0.112)$ \\
Thailand & 1.330 & $(0.722)$
\end{tabular}

Note: The table show results of a LR test for over-identifying restrictions. $\chi^{2}$-tests are presented with $p$ values in parentheses. $*, * *$ and $* * *$ denote statistical significance at the $10 \%, 5 \%$, and $1 \%$ levels, respectively. 
Table 2. Forecast Error Variance Decompositions

\begin{tabular}{lccccccccc}
\hline & $\begin{array}{c}\text { 4 Steps } \\
\text { Lower }\end{array}$ & Upper & & $\begin{array}{c}\text { 8 Steps } \\
\text { Lower }\end{array}$ & Upper & $\begin{array}{c}\text { 12 Steps } \\
\text { Lower } \\
\text { Upper }\end{array}$ \\
\hline Indonesia & 0.031 & -0.020 & 0.082 & 0.032 & -0.019 & 0.082 & 0.032 & -0.019 & 0.082 \\
Malaysia & 0.069 & 0.004 & 0.135 & 0.069 & 0.003 & 0.134 & 0.069 & 0.003 & 0.134 \\
Philippines & 0.008 & -0.019 & 0.035 & 0.008 & -0.019 & 0.036 & 0.008 & -0.019 & 0.036 \\
Singapore & 0.040 & -0.010 & 0.090 & 0.043 & -0.009 & 0.095 & 0.043 & -0.009 & 0.095 \\
Thailand & 0.065 & 0.004 & 0.127 & 0.066 & 0.004 & 0.128 & 0.066 & 0.004 & 0.128 \\
\hline
\end{tabular}

Note: Forecast error variance decompositions for real stock prices for 4, 8, and 12 steps. Lower and upper represent the $90 \%$ lower and upper bounds, respectively. 
Figure 1. Imports from China as Share of Total Imports

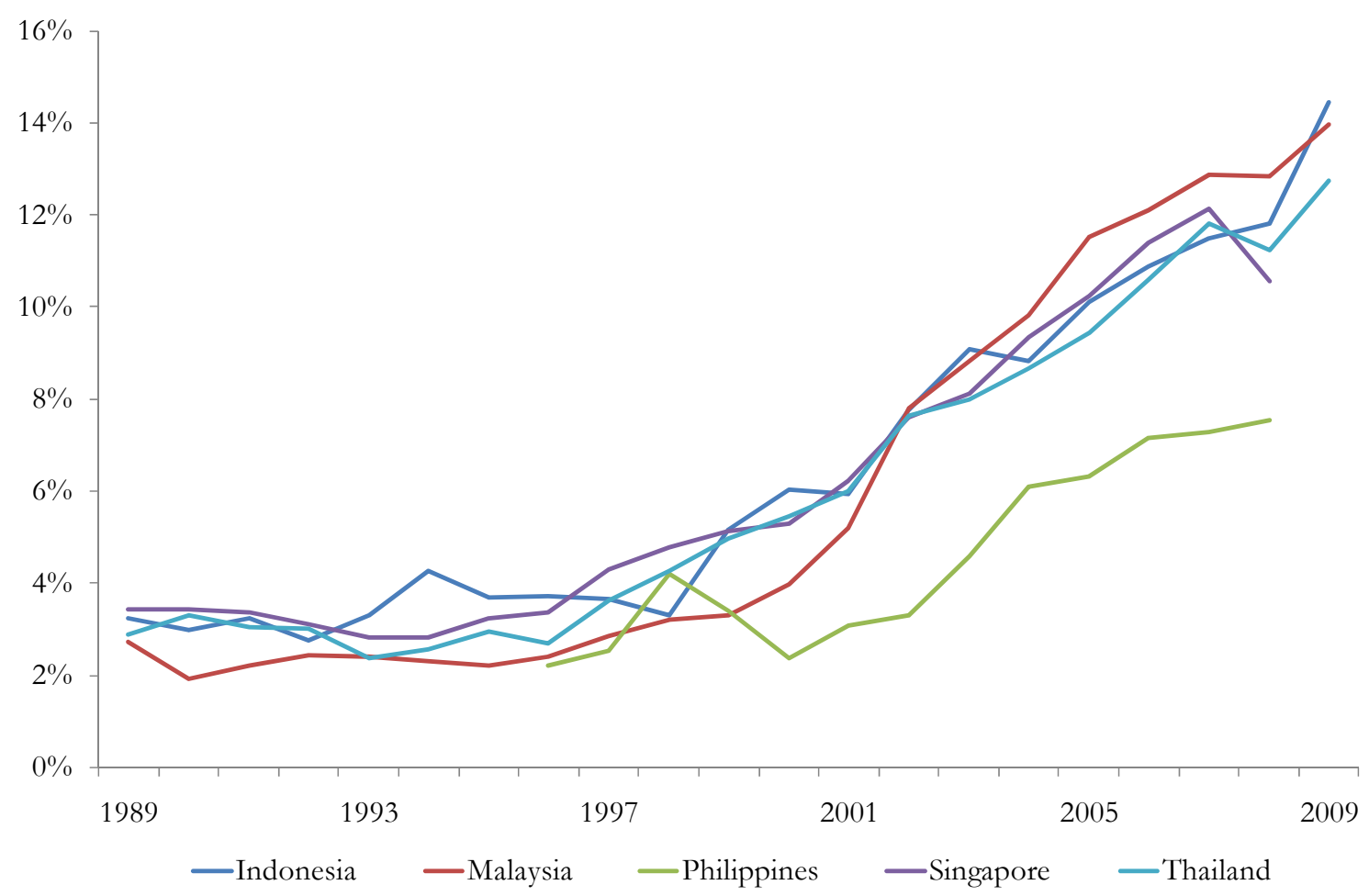

Note: The ratio of imports from People's Republic of China to total imports. Numbers are those reported by respective country and total imports are imports from World in the UN Comtrade Database.

Source: UN Comtrade Database. 
Figure 2. Export to China as Share of Total Exports

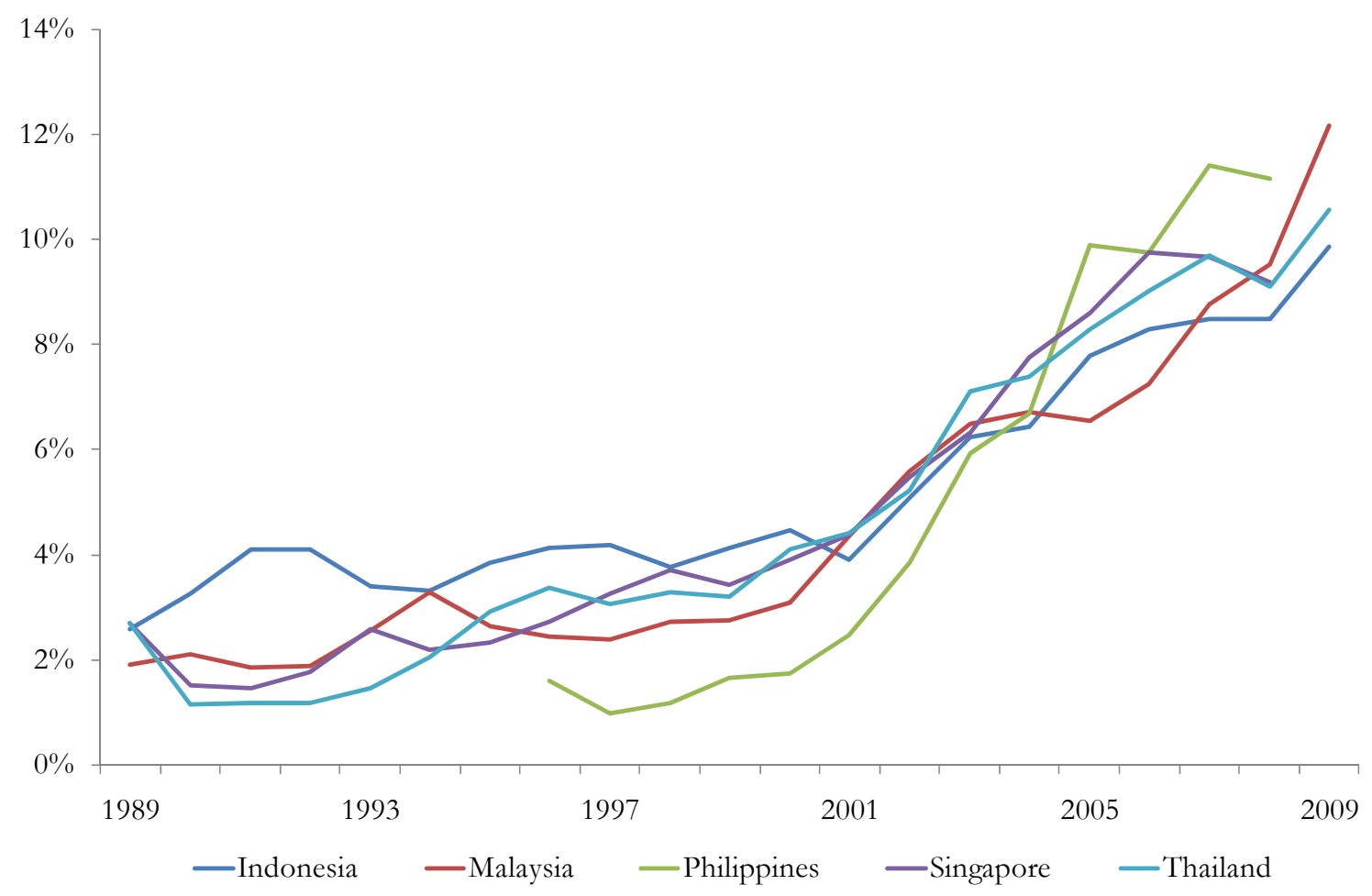

Note: The ratio of exports from People's Republic of China to total exports. Numbers are those reported by respective country and total exports are exports from World in the UN Comtrade Database.

Source: UN Comtrade Database. 
Figure 3. Impulse Response Functions - Indonesia

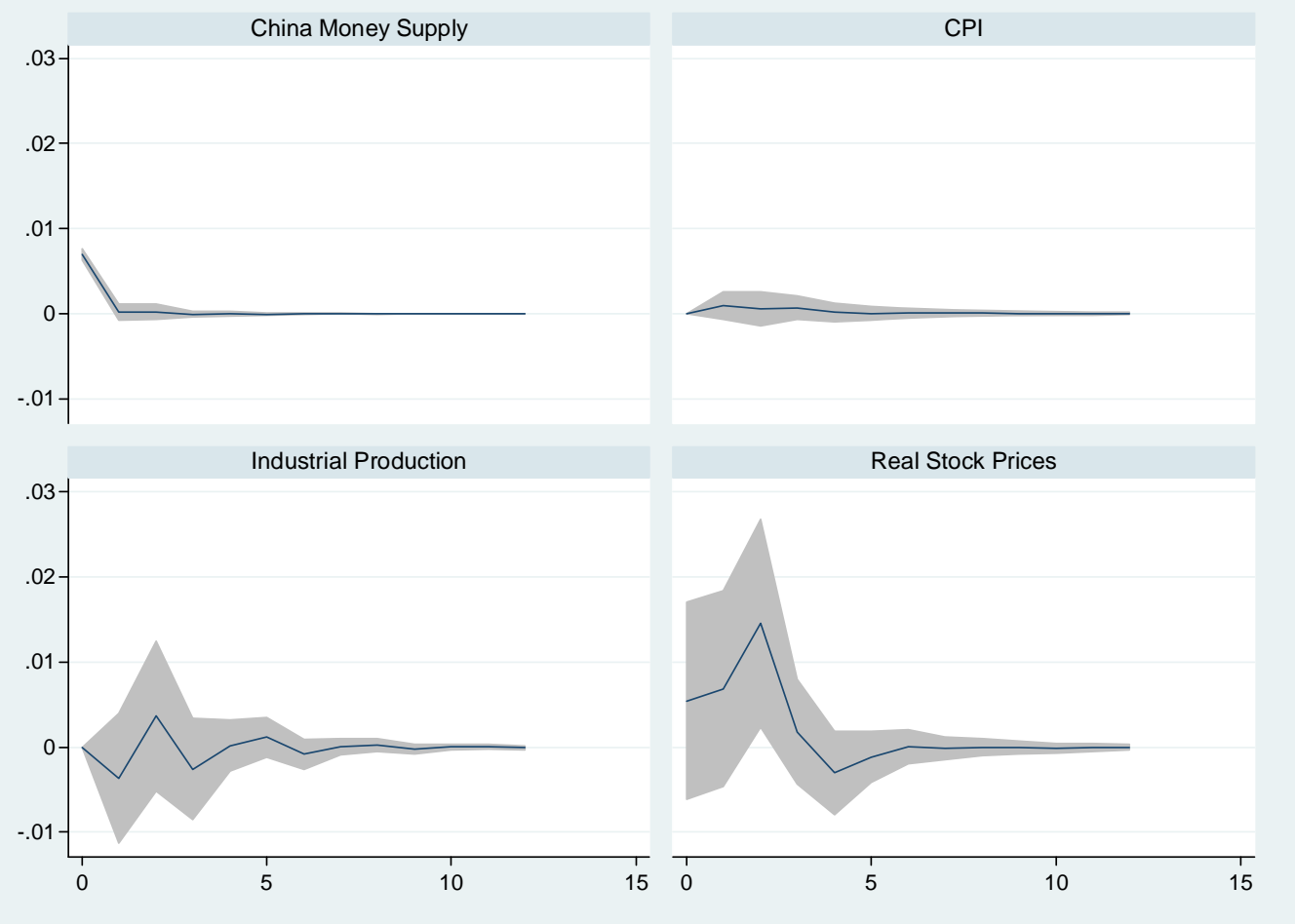

Note: Impulse responses of shocks to China money supply. 
Figure 4. Impulse Response Functions - Malaysia

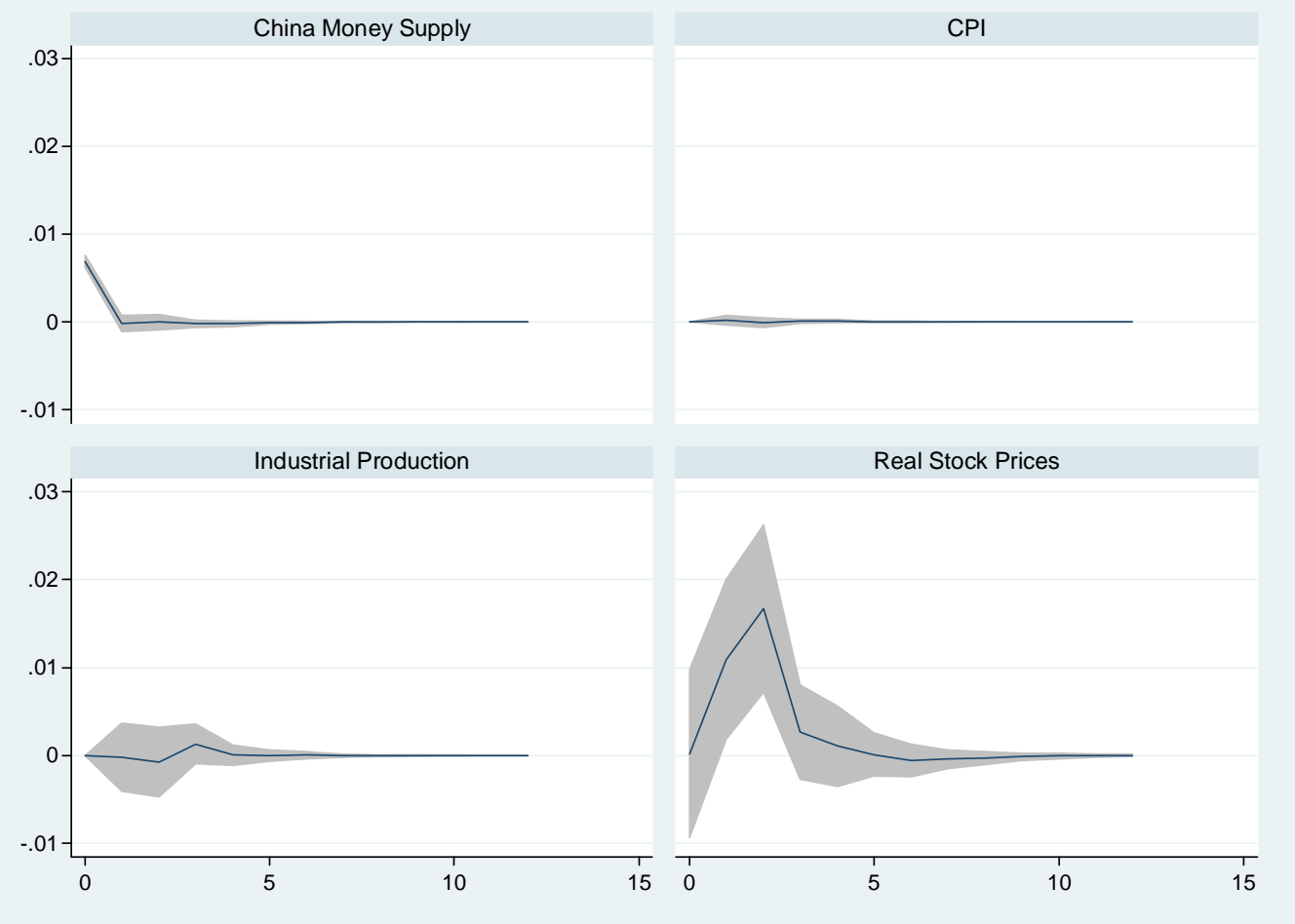

Note: Impulse responses of shocks to China money supply. 
Figure 5. Impulse Response Functions - Philippines

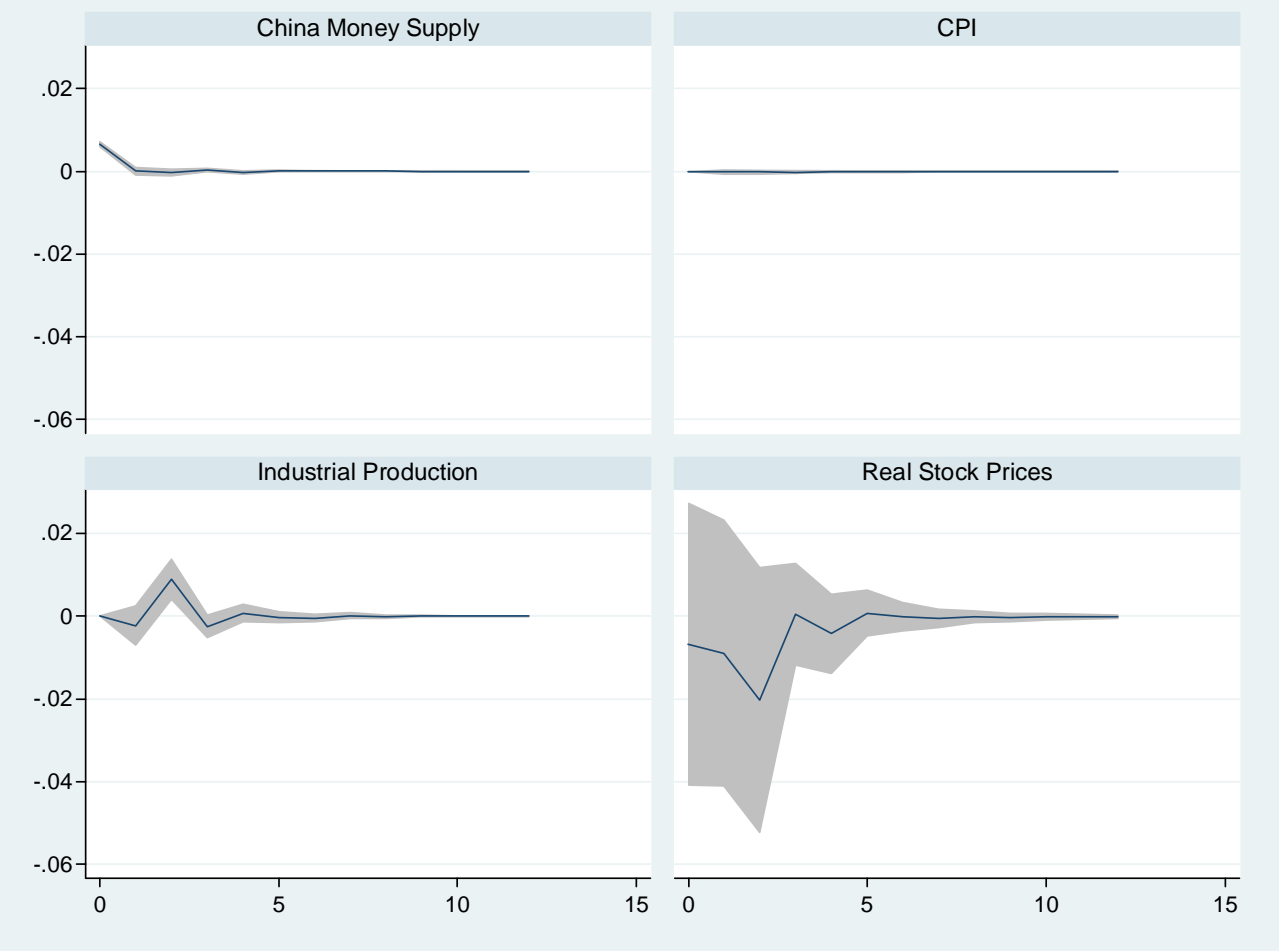

Note: Impulse responses of shocks to China money supply. 
Figure 6. Impulse Response Functions - Singapore
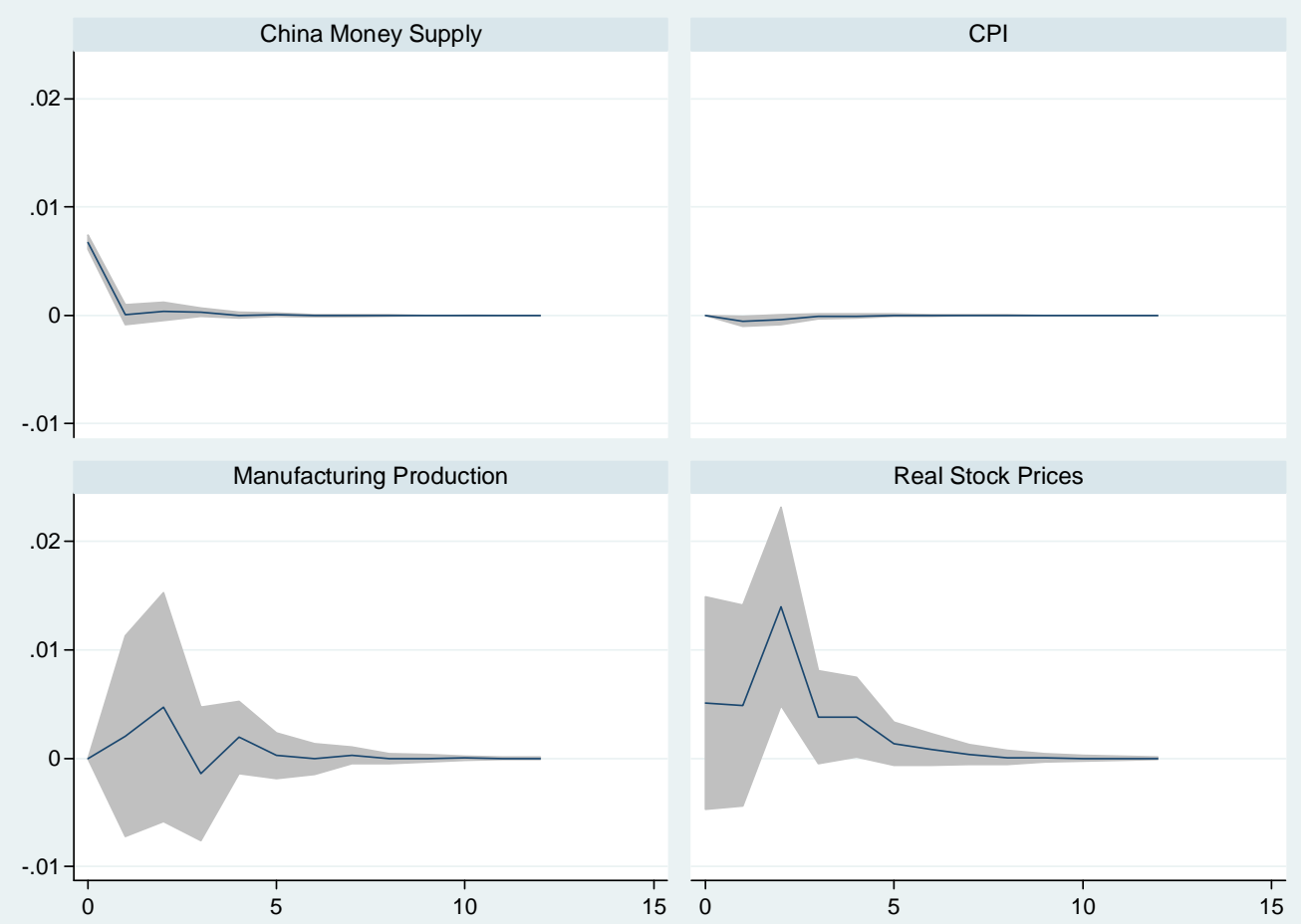

Note: Impulse responses of shocks to China money supply. 
Figure 7. Impulse Response Functions - Thailand

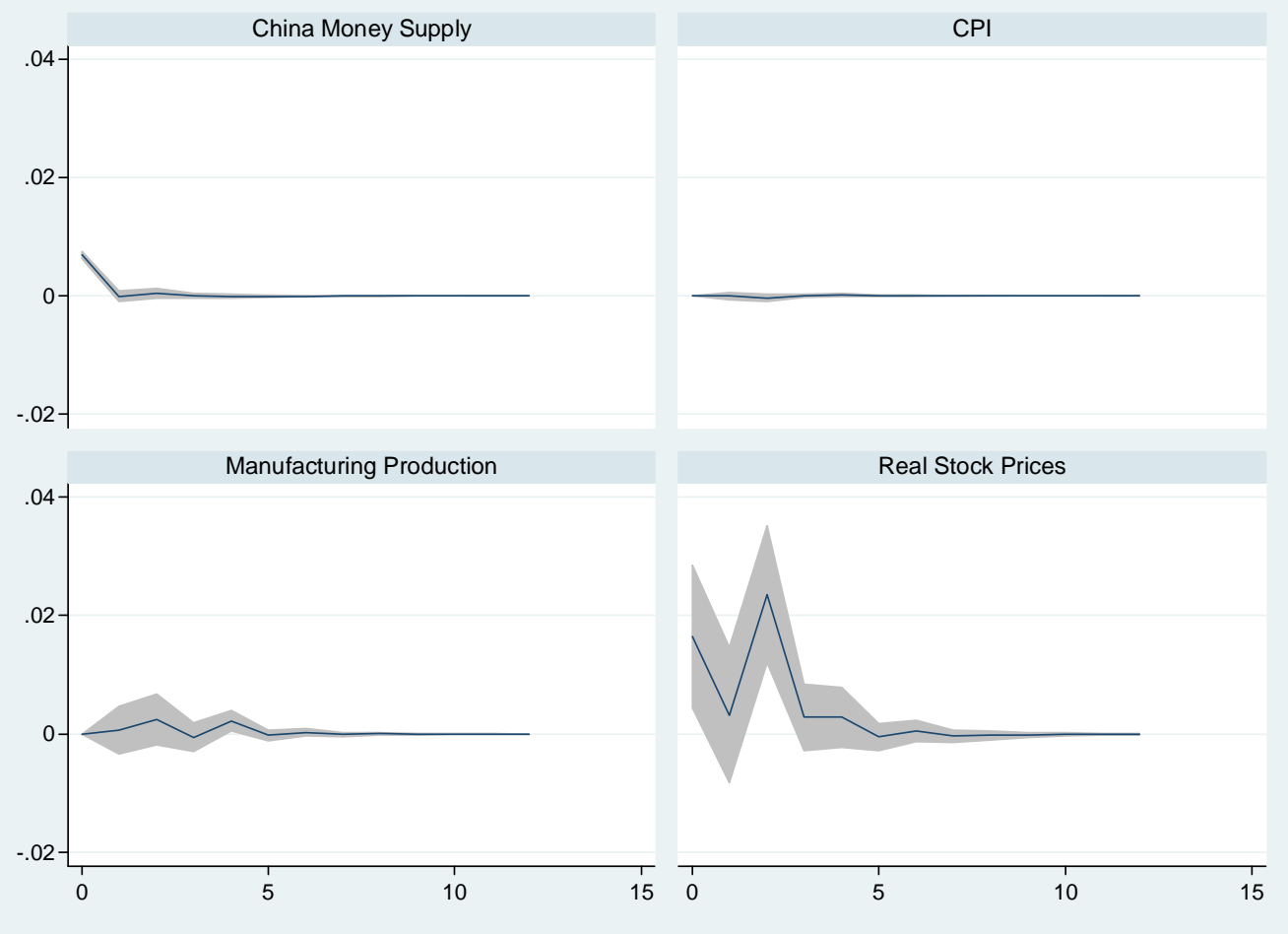

Note: Impulse responses of shocks to China money supply. 